\title{
Biodegradable plastic modification from durian seed starch and shrimp chitosan with the addition of plasticiziers glycerol and polyglycerol using microwaves
}

\author{
Saud Salomo1, Astri Devi Br Pakpahan, Dea Gracella Siagian, Grecy \\ Kristina Tampubolon ${ }^{2}$, Salsabila Afani ${ }^{2}$, Eddiyanto ${ }^{1}$ and Junifa Layla \\ Sihombing, ${ }^{1, *}$
}

'Department of Chemistry, Universitas Negeri Medan, Medan 20221, Indonesia

${ }^{2}$ Department of Physics, Universitas Negeri Medan, Medan 20221, Indonesia

*Corresponding author: JLS, junifalaylasihombing@unimed.ac.id

DOI: $10.24114 / j p k i m . v 13 i 3.29017$

Article history:

Received: 08 September 2021

Revised: 02 November 2021

Accepted: 03 November 2021

\begin{abstract}
Plastic waste takes up to 450 years to decompose. These problems can be overcome by creating other alternatives, one of which is by using biodegradable plastic. Biodegradable plastics are plastics made from natural polymers that are easily degraded by microorganisms. This study aims to examine the effect of the amount of plasticizer on the length of the degradation process and the effect of using microwaves on the length of time for molding biodegradable plastic. This biodegradable plastic is made by combining durian seed starch, shrimp chitosan and plasticizers in the form of glycerol and polyglycerol with volume variations of $1 \mathrm{~mL}, 2 \mathrm{~mL}, 3 \mathrm{~mL}, 4 \mathrm{~mL}$, and $5 \mathrm{~mL}$. This polymerization was carried out using a microwave with a power of 100 watts for 60 minutes. The resulting biodegradable plastics were characterized using the FTIR test, the Mechanical Properties test, the Absorbency test, and the Biodegradation test to determine the quality of the biodegradable plastic. The results of this study indicate the greatest tensile strength value is $1.9768 \mathrm{MPa}$, the largest elongation value is $21.2772 \%$, the smallest water absorption is $45.40 \%$ for 5 minutes, and the largest degraded mass is 0.908 grams for 7 days. Based on this research, it can be concluded that the use of polyglycerol can accelerate the plastic degradation process. In addition, the use of microwaves can speed up the molding time of biodegradable plastics.
\end{abstract}

Keywords: Biodegradable plastic, Durian seed starch, Shrimp chitosan, Glycerol, Microwaves

\section{Introduction}

Plastics are synthetic polymers composed of monomers that are bonded or related to each other. The need for plastic is so great that it triggers environmental problems in the 
world, especially in Indonesia in the form of plastic waste. Plastic waste derived from petroleum raw materials is waste that is difficult to decompose by microbes in the soil. According to Indonesia's domestic waste statistics, plastic waste is ranked second at 5.4 million tons per year or $14 \%$ of the total waste production. This number is expected to increase in line with the needs and purchasing power of the people (Haryati et al. 2017).

By looking at the development of research on biodegradable plastics, generally using natural materials such as starch. One of the raw materials that contains quite a lot of starch is durian seeds by $66.49 \%$. In Indonesia, durian plants are found in all corners of Java and Sumatra, especially in the North Sumatra area, durian production in 2019 reached 90,105 tons and occupied the 4th largest position in Indonesia. Biodegradable plastic made from starch still has several weaknesses, namely it is less resistant to water and its mechanical properties are still low. One way to reduce hydrophilic properties is to mix starch with other hydrophobic biopolymers, namely chitosan. Chitosan also serves to provide the effect of transparency and tensile strength properties of biodegradable plastics (Ritonga, 2018). In addition, a substance in the form of a plasticizer such as glycerol is needed to improve the mechanical properties of biodegradable plastic.

Based on research (Warzukni, 2020) biodegradable plastic with starch raw materials and chitosan and glycerol fillers takes 24 hours for the molding process using an oven and takes 44 days to completely degrade. So to speed up the printing process and the process of biodegradable plastic degradation, an update was carried out where the heating device used was replaced with microwaves and the plasticizer used was replaced with polyglycerol. The purpose of this study was to examine the production process of biodegradable plastic from durian seed starch and shrimp chitosan with the addition of glycerol and polyglycerol plasticizers using microwaves.

\section{Methods}

\subsection{Materials and sample}

The materials used in this study were $5 \mathrm{~kg}$ of durian seeds, $1 \% \mathrm{CaCO}_{3}, 100 \mathrm{~g}$ of shrimp shells, $\mathrm{NaOH}(2 \%, 3.5 \%, 50 \%), 0.1 \mathrm{M} \mathrm{HCl}, \mathrm{pH}$ indicator, aquadest, $\mathrm{H}_{2} \mathrm{SO}_{4} 0.1 \mathrm{M}, \mathrm{C} 6 \mathrm{H} 8 \mathrm{O} 7,1 \%$ $\mathrm{CH}_{3} \mathrm{COOH}$, and glycerol. The tools used in this study were hot plate stirrer, 100 mesh sieve, analytical balance, oven, microwave, desiccator, glass plate $(15 \times 15) \mathrm{cm}, 100 \mathrm{~mL}$ measuring cup, $1000 \mathrm{~mL}, 500 \mathrm{~mL}$ and $250 \mathrm{~mL}$ beaker glass, pipette measuring $5 \mathrm{~mL}$, thermometer, watch glass, stir bar, spatula, blender, mortar and pestle, aluminum foil, polybag, a set of tensile test equipment (Tensile Strength), elongation, FTIR (Fourier Transform Infra Red) and SEM (Scanning Electron Microscope).

\subsection{Durian seed starch isolation}

A total of $5 \mathrm{~kg}$ of durian seed waste was washed first to remove sticky contaminants. The outer sheath and epidermis of the durian seeds were peeled and the inside was cut with a thickness of $\pm 2 \mathrm{~mm}$. Then soaked with $1 \% \mathrm{CaCO}_{3}$ solution for 20 minutes and rinsed again with water until clean. Durian seeds are dried in the sun for 6 hours, then mashed with a blender with a ratio of durian seeds and water that is 1:5 (w/v). The results of the refining are filtered to get the filtrate liquid (starch suspension) which will be deposited for 24-48 hours in the refrigerator until the starch settles completely. The precipitate obtained was 
separated from the clear liquid above and then tested for the $\mathrm{pH}$ of the starch precipitate, if the starch $\mathrm{pH}$ was still alkaline, the washing process was carried out with aquadest and redeposited until a neutral starch pH was obtained. If the starch pH is neutral, the next step is oven at $500 \mathrm{C}$ for \pm 24 hours to dry. The dry starch obtained was ground until smooth and sieved with a 100 mesh sieve to obtain durian seed starch powder and then analyzed by FTIR (Ritonga, 2018).

\subsection{Shrimp chitosan isolation}

A total of 100 grams of shrimp shells were washed and dried in the sun to dry, then mashed using a blender and sieved using a 100 mesh sieve. Shrimp shell powder obtained was deproteinized by mixing shrimp powder and 3.5\% $\mathrm{NaOH}$ solution in a ratio of 1:10 $(\mathrm{m} / \mathrm{v})$ at $900 \mathrm{C}$ at $500 \mathrm{rpm}$ for 2 hours. The results obtained were filtered and washed with distilled water until a neutral $\mathrm{pH}$ was obtained, then the precipitate was oven-dried for 3 hours at $500 \mathrm{C}$ to dry. The results of the deproteination were then demineralized by adding $0.1 \mathrm{M} \mathrm{HCl}$ solution with a ratio of 1:10 (m/v) at $900 \mathrm{C}$ at $500 \mathrm{rpm}$ for 2 hours. The results obtained were filtered and washed with aquadest until a neutral $\mathrm{pH}$ was obtained, then the precipitate was oven-dried for 3 hours at a temperature of $500 \mathrm{C}$ to dry. The chitin obtained was analyzed by FTIR. The result of demineralization is then deacetylated by adding $50 \% \mathrm{NaOH}$ in a ratio of 1:10 ( $\mathrm{m} / \mathrm{v})$ at $900 \mathrm{C}$ at $500 \mathrm{rpm}$ for 2 hours. The results obtained were filtered and washed with distilled water until a neutral $\mathrm{pH}$ was obtained, then the precipitate was oven-dried for 3 hours at 500 C to dry (Astuti et al. 2019). The results of chitosan obtained were analyzed by FTIR.

\subsection{Glycerol polymerization}

A total of $25 \mathrm{~mL}$ of glycerol was added with $2 \% \mathrm{NaOH}$ catalyst and stirred until homogeneous. Then the mixture of glycerol and $\mathrm{NaOH}$ was polymerized using a microwave for 20 minutes with a power of 300 watts. The reaction product is decanted to the top layer which is the result of being analyzed by FTIR (Siregar, 2016).

\subsection{Biodegradable plastic manufacturing}

The starch of durian seeds was weighed as much as 5 grams and dissolved in $100 \mathrm{~mL}$ of distilled water (Purnavita and Utami, 2018). Shrimp chitosan was weighed as much as 1 gram and dissolved in $60 \mathrm{~mL}$ of $1 \% \mathrm{CH}_{3} \mathrm{COOH}$ while stirring with a stirrer for 30 minutes (Said, 2018). After the chitosan dissolved, the durian seed starch solution was mixed into the chitosan solution while stirring and heated to a temperature of $800 \mathrm{C}$. When the temperature of the mixture reaches $700 \mathrm{C}$, plasticizer (glycerol or polyglycerol) is added to the mixture with volume variations of $1 \mathrm{~mL}, 2 \mathrm{~mL}, 3 \mathrm{~mL}, 4 \mathrm{~mL}$, and $5 \mathrm{~mL}$ and is heated again until the temperature reaches $800 \mathrm{C}$. After that, the mixture was cooled down to $600 \mathrm{C}$ and printed on a glass plate. Then the mold is put into the microwave for 60 minutes with 100 watts of power. The prints were put in a desiccator and allowed to stand for 24 hours (Lestari et al. 2017), then the plastic sheet was removed from the glass plate and characterized by good end mechanical, biodegradation, water absorption, and FTIR.

\subsection{Biodegradable test}

Biodegradability testing is carried out to ensure that the material can be properly degraded in the environment (Saputro and Ovita, 2017). Biodegradability testing was carried 182

S. Salomo et al. Plastic modification from durian seed starch and shrimp chitosan 
out using black soil. The simplest quantitative method to characterize polymer biodegradation is to determine the mass loss of degradability of polymeric materials. Mass loss was determined by measuring the mass of polymer before and after biodegradation over a certain period of time. For biodegradability analysis, each sample of biodegradable plastic used in this study was $2 \times 6 \mathrm{~cm}$ in size. Plastic biodegradability analysis takes 7 days (Saputra and Supriyo, 2020).

\subsection{Water absorption test}

This test is carried out to confirm the presence of a bond in the polymer and is determined by adding the degree of bonding of the polymer or the mass of the polymer after regular expansion. By filling the beaker glass with aquadest. Then cut the biodegradable plastic with a size of $3 \times 3 \mathrm{~cm}$. Weigh the initial weight of biodegradable plastic. Put the biodegradable plastic into a glass beaker containing aquadest for 5 minutes. After 5 minutes the biodegradable plastic is removed from the beaker glass and the surface is wiped with a tissue. Weigh the sample weight $(w)$ that has been immersed in a glass beaker (Saputra dan Supriyo, 2020).

$$
\text { Water absorption }(\%)=\frac{\text { mass after }- \text { mass before }}{\text { mass before }} \times 100 \%
$$

\subsection{Thickness test}

The thickness of the biodegradable plastic was measured based on the ASTM D-1005 standard which was carried out at five different places and the results were obtained from the average of the five measurements. The thickness of the biodegradable plastic in this study was measured with a caliper with an accuracy of $0.005 \mathrm{~mm}$ (Warzukni, 2020).

\subsection{Tensile strength test}

Tensile strength testing is carried out with the aim of knowing the limit of the tensile strength of the sample from the test object to a pull and the extent to which the material increases in length based on ASTM D-638-02a. The tensile strength test is carried out by cutting biodegradable plastic with a size of $2 \mathrm{~cm} \times 5 \mathrm{~cm}$, the biodegradable plastic is clamped on the UTM Tensilon-RTF tool and given a load at the bottom (Warzukni, 2020).

2.10 FTIR test

The FTIR test was carried out to determine the functional groups contained in biodegradable plastics. The wavelength used is $4000-500 \mathrm{~cm}^{-1}$ (Astuti et al. 2019).

\section{Results and Discussion}

\subsection{Durian seed starch characterization results}

From the results of this study obtained in $5 \mathrm{~kg}$ of durian seeds produce starch as much as 480 grams with a yield of $9.6 \%$. In the results of the extraction of durian seeds in the form of a brownish white powder on Fig 1. In durian seeds, apart from containing starch, there are also other chemical constituents as shown in Table 1. Based on the table we can conclude that starch content in durian seeds is greater than the other contents.

The presence of protein in durian seed starch which is high enough can induce a browning reaction so that the biodegradable plastic made from durian seed starch is brown 
in color. Starch is composed of straight molecules (amylose) which make starch form a gel when heated and branched molecules (amylopectin) which make starch sticky (Cornelia et al. 2013). The bonds that form the structure of amylose and amylopectin are $\mathrm{C}-\mathrm{H}, \mathrm{C}-\mathrm{O}, \mathrm{O}-\mathrm{H}$ bonds. Analysis FTIR spectra on durian seed starch (Fig 2) showed an absorption at wave number $3278.29 \mathrm{~cm}^{-1}$ indicating O-H group (alcohol), wave number $2926.88 \mathrm{~cm}^{-1}$ indicating C$\mathrm{H}$ group, wave number $1243.36 \mathrm{~cm}^{-1}$ indicating the $\mathrm{C}-\mathrm{O}$ group (alkyl and ether) and 1076.92 $\mathrm{cm}^{-1}$ indicated the C-O group (primary alcohol). Research conducted by Ritonga (2018) also obtained that the results of the FTIR of durian seed starch obtained have shown a wave number which states the $\mathrm{O}-\mathrm{H}$ group at a wave number of $3340.71 \mathrm{~cm}^{-1}$, the $\mathrm{C}-\mathrm{O}$ group at a wave number of $1014.56 \mathrm{~cm}^{-1}$ and $\mathrm{C}-\mathrm{H}$ at a wave number of $1014.56 \mathrm{~cm}^{-1}$, wave $2067.69 \mathrm{~cm}^{-1}$. This is in accordance with previous research which shows the bond $\mathrm{C}-\mathrm{H}, \mathrm{C}-\mathrm{O}, \mathrm{O}-\mathrm{H}$ on durian seed starch.

\section{Table 1}

Durian seed composition

\begin{tabular}{c|c}
\hline Composition & Content (\%) \\
\hline Starch & $66.49 \%$ \\
\hline Water & $27.24 \%$ \\
\hline Ash & $1.19 \%$ \\
\hline Protein & $5.08 \%$ \\
\hline
\end{tabular}

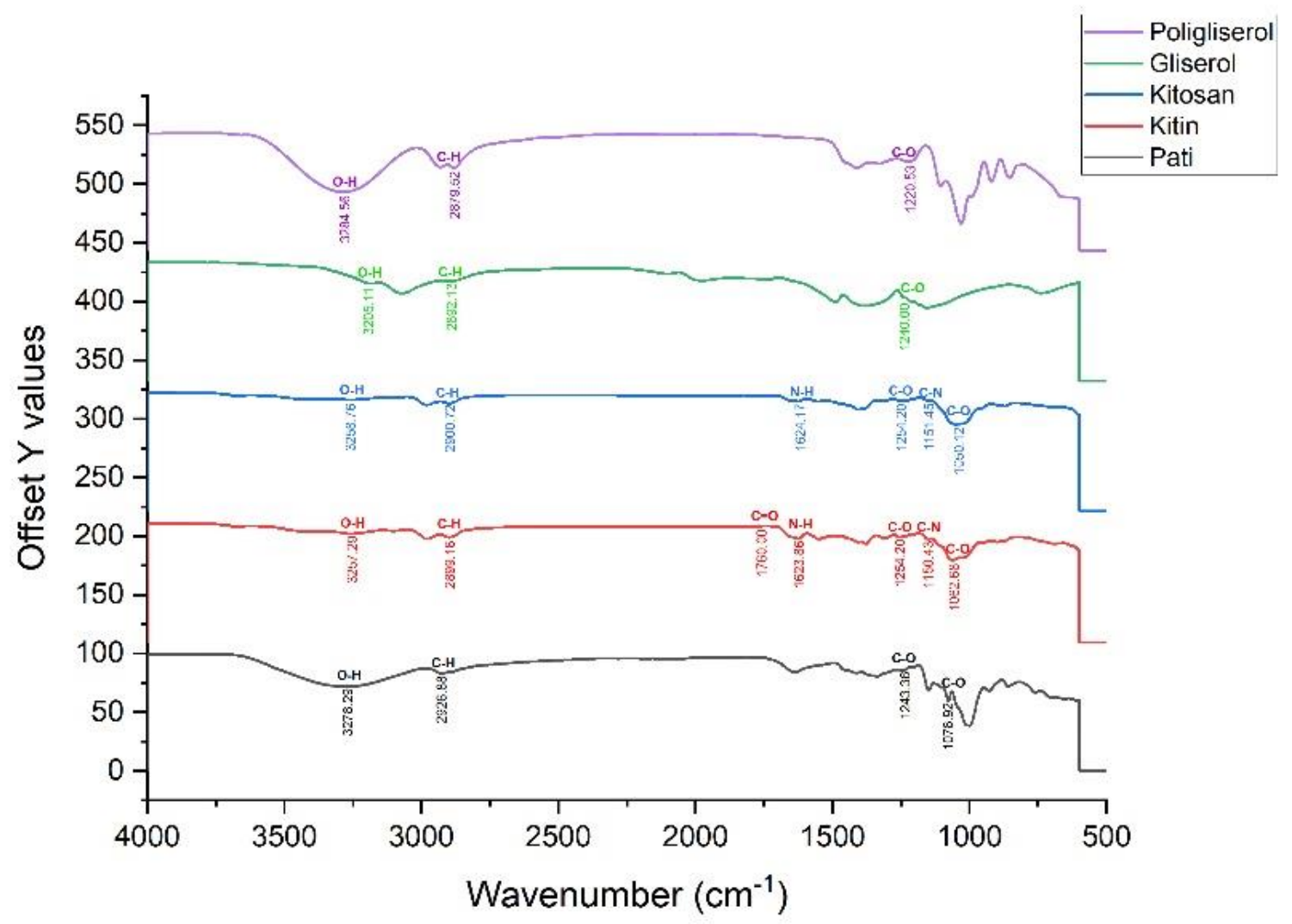

Fig 2. Graph of FTIR analysis results from durian seed starch, chitin, shrimp chitosan, glycerol and polyglycerol 
3.2 Characterization results of chitin and shrimp chitosan

From the results of this study, 100 grams of shrimp shells produced 73 grams of chitin and then 54 grams of chitosan were obtained with a yield of $73.97 \%$. In the extract of shrimp chitosan in the form of a fine white powder on Fig 3.

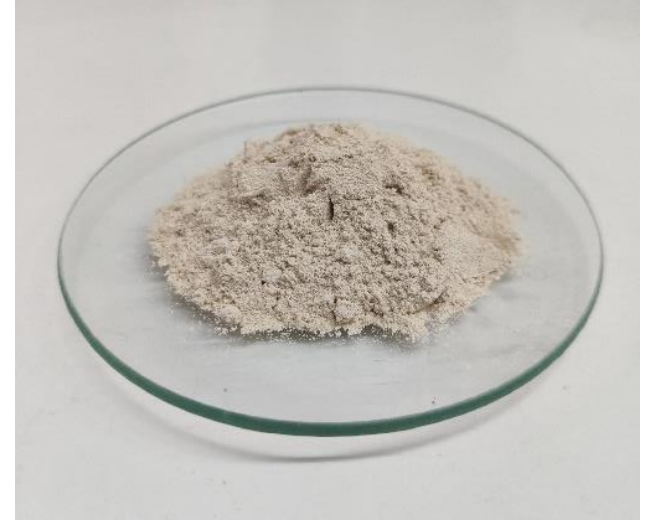

Fig 1. Durian seed starch

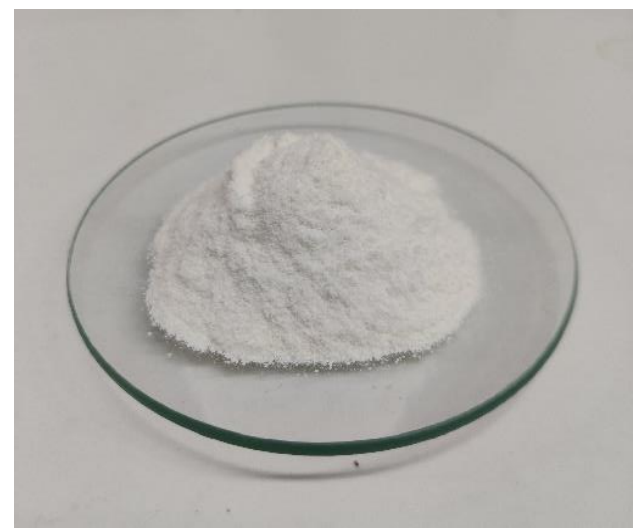

Fig 3. Shrimp chitosan

Chitin is composed of $\mathrm{CN}, \mathrm{NH}, \mathrm{C}=\mathrm{O}, \mathrm{OH}$ and $\mathrm{CO}$ bonds. AnalysisThe FTIR spectra of chitin (Fig 2) showed an absorption at a wave number of $3257.29 \mathrm{~cm}^{-1}$ indicating an $\mathrm{OH}$ group (alcohol), at a wave number of $2899.16 \mathrm{~cm}^{-1}$ indicating a $\mathrm{C}-\mathrm{H}$ group, a wave number of $1760.00 \mathrm{~cm}^{-1}$ indicating a $\mathrm{C}-\mathrm{H}$ group, $\mathrm{C}=\mathrm{O}$ (carboxylic acid), wave number $1150.43 \mathrm{~cm}^{-1}$ indicates a C-N group (amine), wave number $1623.86 \mathrm{~cm}^{-1}$ indicates an $\mathrm{N}-\mathrm{H}$ group (amine) and wave number $1254.20 \mathrm{~cm}^{-1}$ indicates a C-O group ( alkyl and ether) and $1062.68 \mathrm{~cm}^{-1}$ indicates the C-O group (primary alcohol). Research conducted by Azizati (2019) on the FTIR spectra of chitin absorption band in the area of $1627.92 \mathrm{~cm}-1$ which is $\mathrm{C}=\mathrm{O}$ and the absorption band at wave number $1558.48 \mathrm{~cm}^{-1}$ which is $\mathrm{N}-\mathrm{H}$ acetamide, at wave number 2885.51 and $1381.03 \mathrm{~cm}-1$ is $\mathrm{C}-\mathrm{H}$, wave number $3441.01 \mathrm{~cm}^{-1}$ is $\mathrm{O}-\mathrm{H}, \mathrm{C}-\mathrm{N}, \mathrm{N}-\mathrm{H}, \mathrm{C}=\mathrm{O}, \mathrm{O}-\mathrm{H}$ and $\mathrm{C}-\mathrm{O}$ in chitin.

Chitosan is composed of $\mathrm{C}-\mathrm{N}, \mathrm{N}-\mathrm{H}, \mathrm{O}-\mathrm{H}$ and $\mathrm{C}-\mathrm{O}$ bonds. Analysis FTIR spectra of chitosan (Fig 2) showed absorption at a wave number of $3258.76 \mathrm{~cm}^{-1}$ indicating an $\mathrm{O}-\mathrm{H}$ group (alcohol), a wave number of $2900.72 \mathrm{~cm}^{-1}$ indicating a $\mathrm{C}-\mathrm{H}$ group, a wave number of 1624.17 $\mathrm{cm}^{-1}$ indicating an $\mathrm{N}-\mathrm{H}$ group. (amine), wave number $1254.20 \mathrm{~cm}^{-1}$ indicates C-O group (alkyl and ether), wave number $1050.12 \mathrm{~cm}^{-1}$ indicates C-O group (primary alcohol), and wave number $1151.45 \mathrm{~cm}^{-1}$ indicates $\mathrm{C}-\mathrm{N}$ group (amine). Acording to Azizati (2019) in the FTIR spectra of chitosan, there are absorption peaks in the area of $3448 \mathrm{~cm}^{-1}(\mathrm{~N}-\mathrm{H}$ and $\mathrm{O}-\mathrm{H}$ from chitosan), 2877 and $1381 \mathrm{~cm}^{-1}(\mathrm{C}-\mathrm{H}), 1597 \mathrm{~cm}^{-1}$ (NH2 which may overlap with amide II), $1157 \mathrm{~cm}^{-}$ ${ }^{1}$ (C-O-C bridge), $1087 \mathrm{~cm}^{-1}$ (C-O). This is in accordance with previous research which shows the bond $\mathrm{C}-\mathrm{N}, \mathrm{N}-\mathrm{H}, \mathrm{O}-\mathrm{H}$ and $\mathrm{C}-\mathrm{O}$ in chitosan.

\subsection{Glycerol characterization results}

Glycerol is composed of $\mathrm{O}-\mathrm{H}, \mathrm{C}-\mathrm{H}, \mathrm{C}-\mathrm{O}$ bonds. Analysis FTIR spectra on glycerol (Fig 2) shows absorption at wave number $3205.11 \mathrm{~cm}^{-1}$ which indicates $\mathrm{O}-\mathrm{H}$ group (alcohol), wave number $2892.13 \mathrm{~cm}^{-1}$ indicates $\mathrm{C}-\mathrm{H}$ group and wave number $1240.00 \mathrm{~cm}^{-1}$ indicates $\mathrm{C}-\mathrm{O}$ (alkyl) group. According to research (Wardana et al. 2019) the resulting FTIR spectrum shows a wave number of $3252 \mathrm{~cm}^{-1}$ showing an O-H group, a wave number of around $2923-2854 \mathrm{~cm}^{-1}$ showing methyl and methylene groups in $\mathrm{C}-\mathrm{H}$, and a wave number of $1300-1000 \mathrm{~cm}^{-1}$ appears 
$\mathrm{C}-\mathrm{O}$ uptake. This is in accordance with previous research which shows the bond $\mathrm{O}-\mathrm{H}, \mathrm{C}-\mathrm{H}, \mathrm{C}-\mathrm{O}$ on glycerol.

\subsection{Polyglycerol characterization results}

Polyglycerol is composed of O-H, C-H, C-O bonds. Analysis FTIR spectra on polyglycerol (Fig 2) shows absorption at wave number $3284.56 \mathrm{~cm}^{-1}$ which indicates $\mathrm{O}-\mathrm{H}$ group (alcohol), wave number $2879.52 \mathrm{~cm}^{-1}$ indicates $\mathrm{C}-\mathrm{H}$ group and wave number $1220.53 \mathrm{~cm}^{-1}$ indicates $\mathrm{C}-\mathrm{O}$ (ether) group. Siregar's research (2016) the resulting FTIR spectrum shows that polyglycerol is polar which still has an alcohol O-H group present at a wave number of $3279.24 \mathrm{~cm}^{-1}$, in the absorption band wave number $2879.18 \mathrm{~cm}^{-1}$ shows a C-H group and at an absorption band with a wave number of $2879.18 \mathrm{~cm}^{-1}$, it shows a C-H group wave $1266.86 \mathrm{~cm}^{-1}$ shows the C-O ester group. This is in accordance with previous research which shows the bond $\mathrm{O}-\mathrm{H}, \mathrm{C}-\mathrm{H}, \mathrm{C}-$ O on glycerol.

\subsection{Results characteristics of biodegradable plastics}

The biodegradable plastic produced in this research is brown in color due to the starch content of durian seeds, slightly transparent due to the chitosan content. This plastic has elastic properties and has a slightly rough texture due to the durian seed starch on Fig 4.

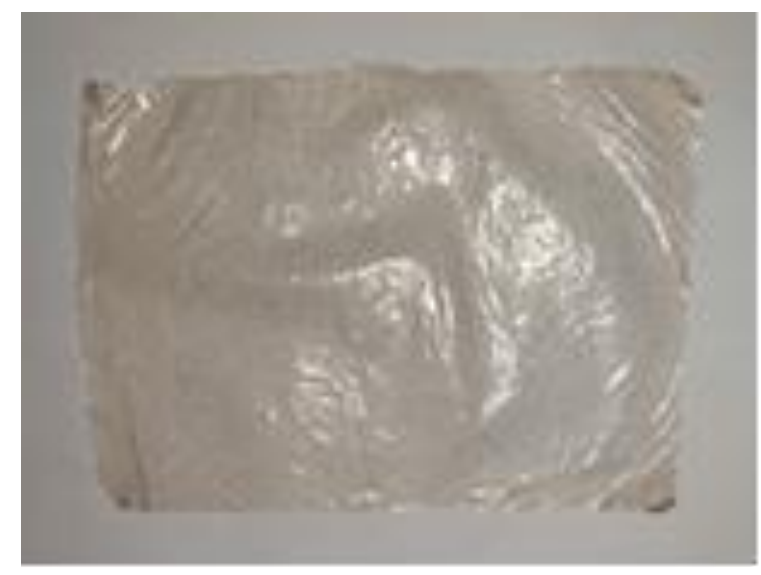

Fig 4. Biodegradable plastic

3.6 Results of thickness, tensile strength and elongation measurement

Thickness is measured using ASTMD-1005which was carried out on plastics containing $5 \mathrm{~g}$ of starch and $1 \mathrm{~g}$ of chitosan using various plasticizers in the form of glycerol and polyglycerol. The thickness of the biodegradable plastic in this study was measured with a digital caliper with an accuracy of $0.05 \mathrm{~mm}$. Tensile strength testing is done by cutting biodegradable plastic measuring $2 \mathrm{~cm} \times 5 \mathrm{~cm}$, biodegradable plastic is clamped on the tool and given a load at the bottom.

The percentage of elongation is the percentage increase in the length of the sample before the tensile strength test is carried out and after the tensile strength test is carried out. The percent elongation value is obtained from the physical properties of bioplastics which show the maximum ability of elongated bioplastics to obtain tensile forces until they break. The results of the thickness test, tensile strength and percent elongation are listed in the Table 2. 
Table 2

Test results tensile strength, elongation and thickness of biodegradable plastics

\begin{tabular}{|c|c|c|c|c|}
\hline $\begin{array}{c}\text { Starch: } \\
\text { Chitosan (g/g) }\end{array}$ & Glycerol (mL) & $\begin{array}{c}\text { Elongation } \\
(\%)\end{array}$ & $\begin{array}{l}\text { Tensile Strength } \\
(\mathrm{MPa})\end{array}$ & $\begin{array}{c}\text { Thickness } \\
(\mathrm{cm})\end{array}$ \\
\hline \multirow{5}{*}{$5: 1$} & 1 & 21.2772 & 1.9768 & 0.0115 \\
\hline & 2 & 17.41192 & 1.2825 & 0.0100 \\
\hline & 3 & 10.361 & 1.2391 & 0.0200 \\
\hline & 4 & 12.66912 & 0.3369 & 0.1300 \\
\hline & 5 & 8.0498 & 0.1712 & 0.0125 \\
\hline $\begin{array}{c}\text { Starch: } \\
\text { Chitosan (g/g) }\end{array}$ & $\begin{array}{l}\text { Polyglycerol } \\
(\mathrm{mL})\end{array}$ & $\begin{array}{c}\text { Elongation } \\
(\%)\end{array}$ & $\begin{array}{c}\text { Tensile Strength } \\
(\mathrm{MPa})\end{array}$ & $\begin{array}{c}\text { Thickness } \\
(\mathrm{cm})\end{array}$ \\
\hline \multirow{5}{*}{$5: 1$} & 1 & 9.20448 & 0.9391 & 0.0125 \\
\hline & 2 & 8.2496 & 0.5065 & 0.0125 \\
\hline & 3 & 14.70152 & 0.2197 & 0.0125 \\
\hline & 4 & 5.41944 & 0.0149 & 0.0120 \\
\hline & 5 & 19.4446 & 0.2137 & 0.0125 \\
\hline
\end{tabular}

In Table 2 it can be seen that the thickness of the largest biodegradable plastic in the glycerol plasticizer variation is $0.130 \mathrm{~cm}$ in the starch variation: $100 \%$ chitosan: $20 \%$ and $80 \%$ glycerol and the smallest thickness is $0.010 \mathrm{~cm}$ in the starch variation: $100 \%$ chitosan: $20 \%$ and glycerol 40. \%. While the plasticizer variation of polyglycerol, the largest thickness is $0.125 \mathrm{~cm}$ in starch variation: $100 \%$ chitosan: $20 \%$ and glycerol $20 \%, 40 \%, 60 \%$ and $100 \%$ and the smallest thickness is $0.0120 \mathrm{~cm}$ in starch variation: $100 \%$ chitosan: $20 \%$ and glycerol $80 \%$. The thickness of the plastic should be influenced by the volume concentration of the plasticizer so as to increase the amount of dissolved solids contained in the plastic film solution. However, in the research conducted there are still errors, namely the volume of solution in each plastic film printing is not the same.

In the tensile strength test and the percent elongation of biodegradable plastics, it can be seen that the largest plastic tensile strength in the glycerol plasticizer variation is 1.9768 MPa with the \% elongation $21.27 \%$ in the starch variation: $100 \%$ chitosan: $20 \%$ and $20 \%$ glycerol while and the smallest tensile strength. namely $0.1712 \mathrm{MPa}$ with \% 8.04\% elongation with starch variations: $100 \%$ chitosan: $20 \%$ and $100 \%$ glycerol. While in the variation of plasticizer polyglycerol the greatest tensile strength is $0.9391 \mathrm{MPa}$ with \% elongation $9.20 \%$ in starch variations: $100 \%$ chitosan: $20 \%$ and glycerol $20 \%$, and the smallest tensile strength is 0.0149 MPa with \% elongation $19.44 \%$ in starch variations: $100 \%$ chitosan: $20 \%$ and $80 \%$ glycerol. The more plasticizer added to the plastic will cause the value of the tensile strength of the plastic to decrease and the percent elongation to increase. Plasticizers can weaken the intermolecular forces of adjacent macromolecular chains and cause a reduction in mechanical strength. However, in this study there was still an error in the percent elongation test because the mixing was not homogeneous so that the insertion of the plasticizer into the plastic matrix did not take place perfectly. 
The interaction between glycerol, chitosan and starch as in Fig 5 shows the suitability where the addition of plasticizers (glycerol or polyglycerol) can make biodegradable plastic films more elastic so that the elongation value can increase but the tensile strength value decreases (Nafiyanto, 2019).

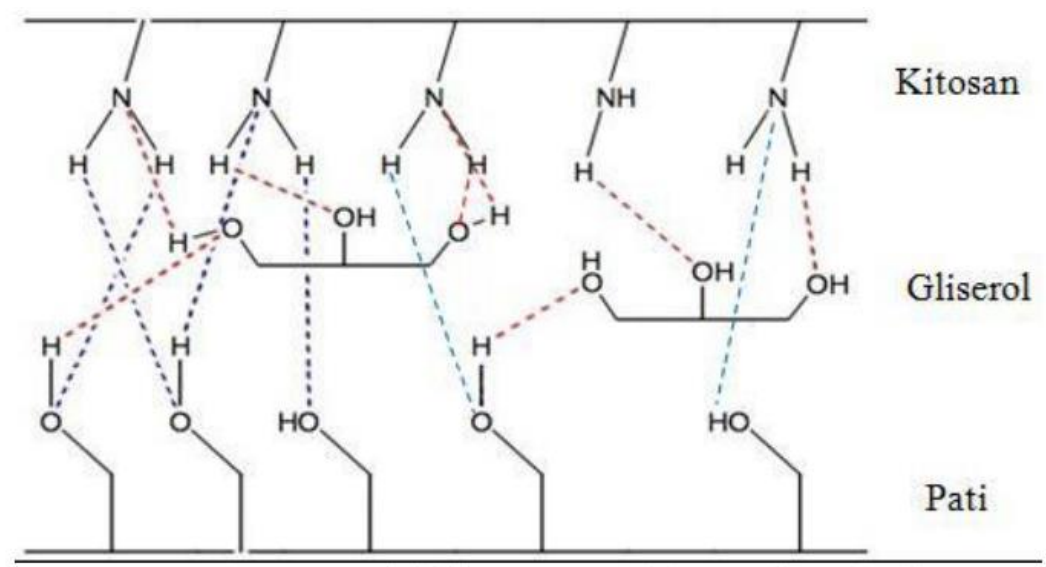

Fig 5. Hydrogen interaction between chitosan-glycerol-starch (Nafiyanto, 2019)

\subsection{Results of FTIR Mikro microstructure analysis}

FTIR (Fourier Transform Infra Red) analysis aims to identify the functional groups of the components that make up Biodegradable Plastics. Functional group analysis was performed using the FTIR NICOLET IS 10 (38/IKA/MT). The results of FTIR biodegradable plastics with the main ingredients of durian seed starch and shrimp chitosan with variations of plasticizers, namely glycerol and polyglycerol are presented on Fig 6 .

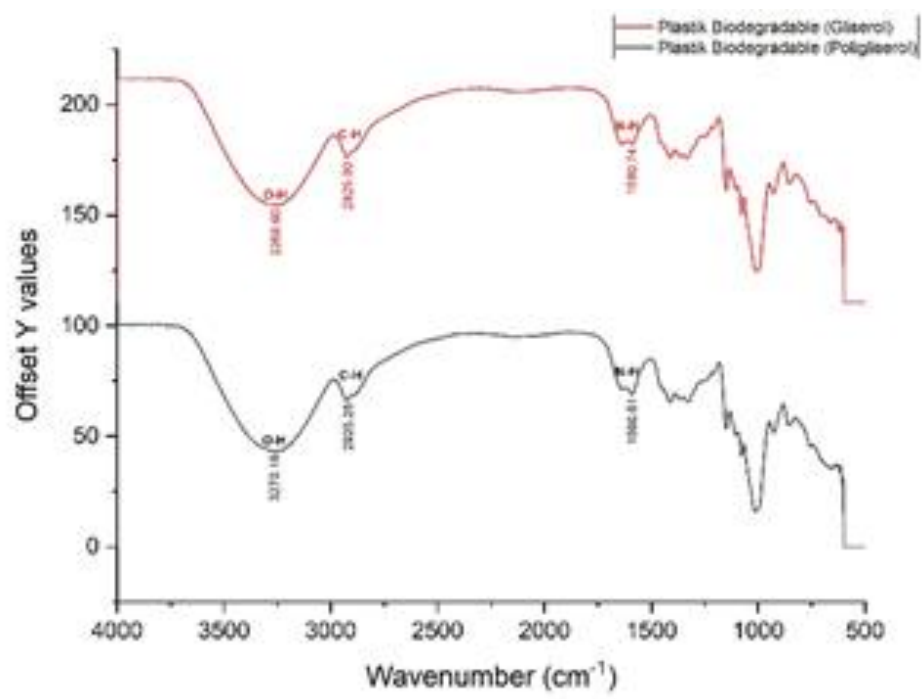

Fig 6. Graph of FTIR Analysis Results of Biodegradable Plastics (Polyglycerol) and Biodegradable Plastics (Glycerol).

Analysis of FTIR Spectra on glycerol variation plastic showed absorption at wave number $3268.60 \mathrm{~cm}-1$ indicating $\mathrm{OH}$ group, wave number $2925.00 \mathrm{~cm}-1$ indicating $\mathrm{CH}$ group, and 
wave number $1590.74 \mathrm{~cm}-1$ indicating NH group. According to research (Nafiyanto, 2019) the resulting bioplastic still has its constituent groups, namely the cluster of durian seed starch, chitosan and glycerol, namely at wave numbers $3425.58 \mathrm{~cm}^{-1}$ indicating O-H group, 2931.80 $\mathrm{cm}^{-1}$ indicating $\mathrm{C}-\mathrm{H}$ group, $1653.64 \mathrm{~cm}^{-1}$ shows the N-H group. Analysis of FTIR spectra on polyglycerol variation plastics showed absorption at wave number $3270.16 \mathrm{~cm}^{-1}$ indicating O$\mathrm{H}$ group, wave number $2925.25 \mathrm{~cm}^{-1}$ indicating $\mathrm{C}-\mathrm{H}$ group, and $1590.61 \mathrm{~cm}^{-1}$ indicating $\mathrm{NH}$ group.

\subsection{Absorption test results}

Absorption test is carried out to ensure the presence of a bond in the polymer and is determined by adding the degree of bonding of the polymer or the mass of the polymer after regular expansion. The results of the absorption test are shown in the following graph on Fig 7.

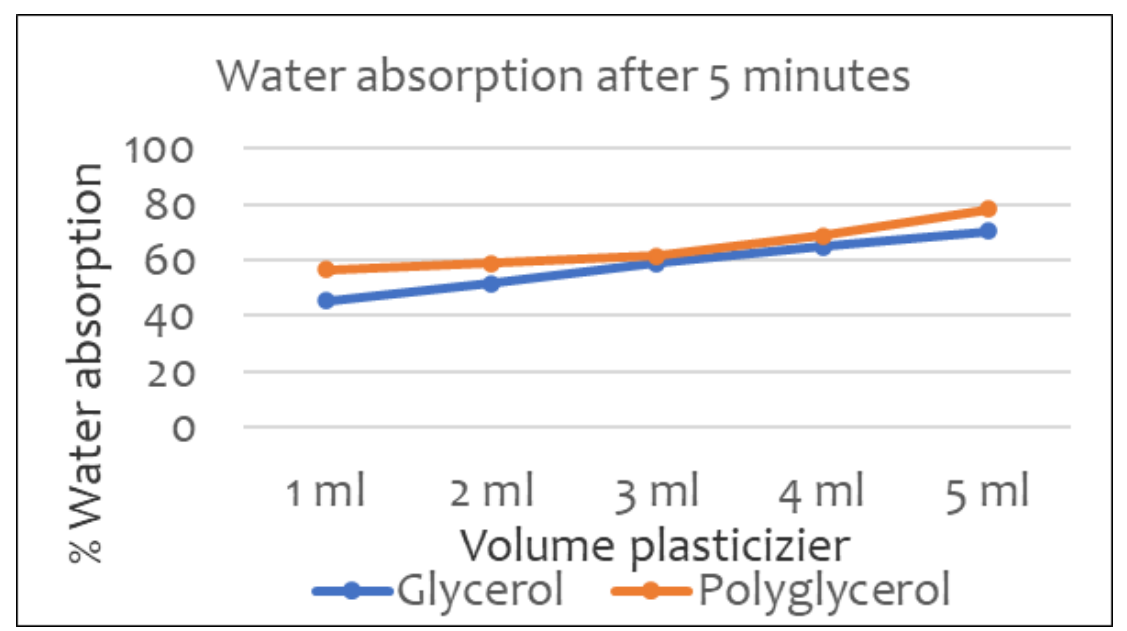

Fig 7. Graph of absorption of biodegradable plastic to water after 5 minutes

The graph in Figure 7 shows the effect of adding plasticizers to the water absorption capacity of biodegradable plastics. The maximum percentage of plastic absorption obtained with the addition of the platicizier glycerol variation was $70.31 \%$ using the ratio of starch: chitosan 100\%: $20 \%$ and glycerol 100\%. The minimum percentage of plastic absorption obtained with the addition of the platicizier glycerol variation was $45.40 \%$ using the ratio of starch: chitosan 100\%: 20\% and glycerol 20\%. Meanwhile, the maximum absorption percentage of biodegradable plastic obtained from the addition of the polyglycerol platicizier variation was $78.32 \%$ using the ratio of starch: chitosan $100 \%: 20 \%$ and polyglycerol $100 \%$. The minimum percentage of biodegradable plastic absorption obtained by the addition of the polyglycerol platicizier variation was $56.57 \%$ using a starch: chitosan ratio of 100\%: $20 \%$ and 20\% polyglycerol. The more plasticizer added, the easier it will be for the plastic film to absorb water. Glycerol and polyglycerol have hydrophilic properties and have enough $-\mathrm{OH}$ groups so that they can bind to water through hydrogen interactions.

\subsection{Biodegradable plastic biodegradation test results}

Biodegradation is one of the observation parameters that can indicate whether bioplastics are environmentally friendly or not. The media used is soil because in the soil 
there are many types of microorganisms (fungi, bacteria and algae) and in large quantities, so that it will support the degradation process that will be carried out (Apriani and Sedyadi, 2015). The Biodegradation Test Process is carried out for 7 days of burial in the soil and then the percentage reduction in mass that occurs in biodegradable plastic is calculated. From testing the ability to be degraded, the results are shown in the following graph on Fig 8 .

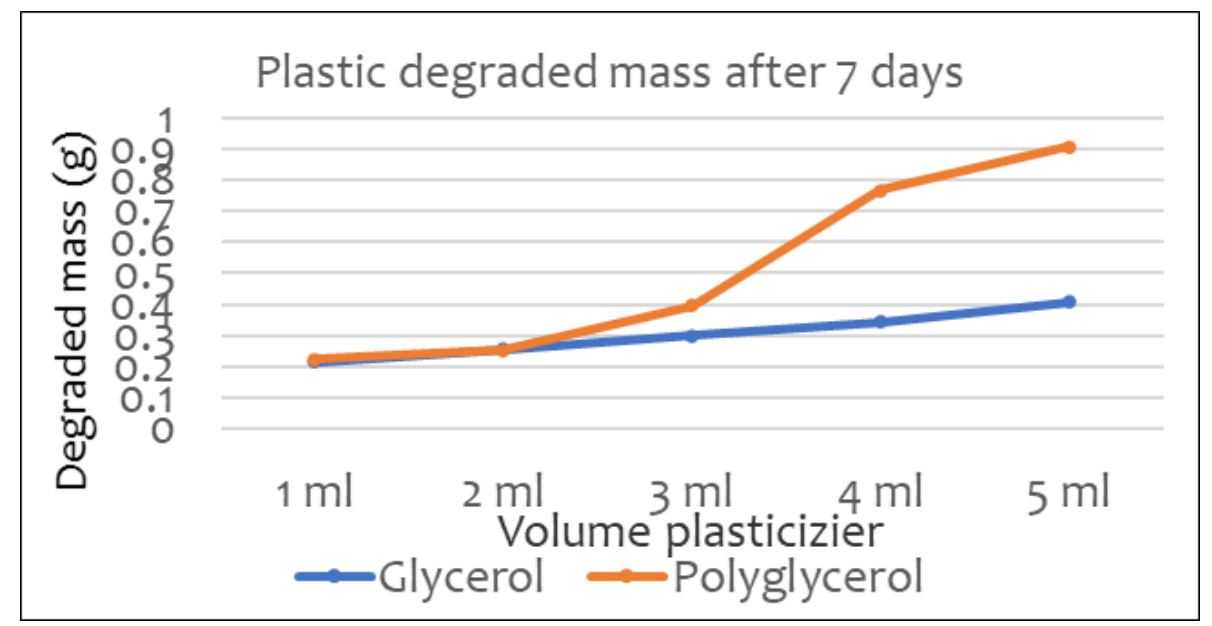

Fig 8 . Degraded plastic mass graph after 7 days

Graphics on Fig 8 showed the effect of adding plasticizer to the ability of biodegradable plastic to be degraded. The maximum degraded mass of plastic film obtained with the addition of glycerol platicizer variation was 0.407 grams from the initial mass of plastic, using a starch: chitosan ratio of 100\%: $20 \%$ and glycerol $100 \%$. The minimum degraded mass of plastic film obtained with the addition of a glycerol platicizer variation was 0.214 grams from the initial mass of biodegradable plastic, using a starch: chitosan ratio of $100 \%: 20 \%$ and glycerol $20 \%$. Meanwhile, the maximum degraded mass of plastic film obtained with the addition of the polyglycerol platicizer variation was 0.908 grams from the initial mass of the plastic, using a starch: chitosan ratio of $100 \%: 20 \%$ and polyglycerol $100 \%$. The minimum degraded mass of biodegradable plastic film obtained with the addition of the polyglycerol platicizier variation was 0.222 gram from the initial mass of the plastic, using the ratio of starch: chitosan 100\%: $20 \%$ and glycerol $20 \%$. The more plasticizer added, the easier it will be for the plastic film to degrade. Glycerol and polyglycerol have hydrophilic properties that accelerate the absorption of water and the plastic film has a high humidity level which causes the polymer chain to be cut shorter by microorganisms.

\section{Conclusion}

Based on the results of the study it can be concluded: (1) The process of printing biodegradable plastic films using microwaves only takes 60 minutes with a power of 100 watts, this shows that the use of microwaves in plastic printing is more efficient than using an oven; (2) The greatest tensile strength value was obtained from the composition of starch: chitosan: glycerol, namely 100\%: $20 \%: 20 \%$ (rph) of $1.9768 \mathrm{MPa}$. The greatest elongation value was obtained from the composition of starch: chitosan: glycerol, namely 100\%: $20 \%: 20 \%$ (rph) of $21.2772 \%$. In the elongation test, the results obtained are not in accordance with the theory. This is because the volume of solution in each plastic film 
printing is not the same; (3) The smallest percentage of water absorption in biodegradable plastic with variations of glycerol plasticizer was obtained from the composition of starch: chitosan: glycerol, namely 100\%: $20 \%: 20 \%$ (rph) of $45.40 \%$. While the smallest percent of water absorption in biodegradable plastics with variations of polyglycerol plasticizer obtained from the composition of starch: chitosan: glycerol, namely $100 \%: 20 \%: 20 \%(\mathrm{rph})$ of 56.57\%; (4) The largest degraded mass of biodegradable plastic was obtained from the composition of starch: chitosan: polyglycerol, namely 100\%: $20 \%: 100 \%$ (rph) of 0.908 grams for 7 days; (5) The biodegradable plastic produced in this research is suitable to be used as plastic wrapping for fruits because of its fast-degrading nature.

\section{Acknowledgment}

Thank you to SIMBELMAWA Ministry of Education, Culture, Research and Technology of the Republic of Indonesia for funding PKM-RE with contract number 1126/UN33.III/KM/2021.

\section{References}

Apriyani, M., \& Sedyadi, E. (2015). Synthesis and characterization of biodegrdable plastic from casava starch and Aloe vera extract with glycerol plasticizer. Jurnal Sains Dasar, 4(2), 145-152. DOI:10.21831/jsd.v4i2.9090

Astuti, A. W., Kusuma, H. H., \& Kumila, B. N. (2019). Pembuatan dan karakterisasi plastik biodegradable berbahan dasar ampas ubi kayu dan kulit udang. Al-Fiziya: Journal of Materials Science, Geophysics, Instrumentation and Theoretical Physics, 2(2), 119-128. DOI: 10.15408/fiziya.v2i2.12407

Azizati, Z. (2019). Pembuatan dan karakterisasi kitosan kulit udang galah. Walisongo Journal of Chemistry, 2(1), 10-16. DOI:10.21580/wjc.v3i1.3878

Cornelia, M., Syarief, R., Effendi, H., \& Nurtama, B. (2013). Pemanfaatan pati biji durian (Durio zibethinus Murr.) dan pati sagu (Metroxylon sp.) dalam pembuatan bioplastik. Jurnal Kimia dan Kemasan, 35(1), 20-29. DOI:10.24817/jkk.v35i1.1869

Haryati, S., Rini, A. S., \& Safitri, Y. (2017). Pemanfaatan biji durian sebagai bahan baku plastik biodegradable dengan plasticizer giserol dan bahan pengisi $\mathrm{CaCO}_{3}$. Jurnal Teknik Kimia, 23(1), 1-8.

Lestari, N. S., Armina, R. S. N., Prabowo, R. A., Riswanti, P. A., Wulansari, R., \& Triwiyatno, A. (2017). Formula plastik biodegradable berbahan dasar pati sukun dan Carboxylmethyl Cellulose (CMC) dari tongkol jagung dengan reagen gliserol. Prosiding SNST Ke-8. 23, August 2017, Semarang, Indonesia. 83-87.

Nafianto, I. (2019). Pembuatan plastik biodegradable dari limbah bonggol pisang kepok dengan plasticizer gliserol dari minyak jelantah dan komposit kitosan dari limbah cangkang bekicot (Achatina fullica). Integrated Lab Journal, 7(1), 75-89. DOI:10.5281/zenodo.2656812

Purnavita, S., \& Utami, W. T. (2018). Pembuatan plastik biodegradable dari pati aren dengan penambahan Aloe vera. Jurnal Inovasi Teknik Kimia, 3(2), 31-35. DOI:10.31942/inteka.v3i2.2488 
Ritonga, F. S. (2018). Bioplastik dari pati biji durian berpengisi kitosan (menggunakan pelarut asam format dan plasticizer gliserol) sebagai plastik pengemas minyak. Thesis. Program Studi Teknik Kimia, Universitas Sumatera Utara. Medan.

Said, A. (2018). Sintesis plastik biodegradable berbahan komposit pati sagu-kitosan sisik ikan katamba (Lethrinus lentjam). Quantum: Jurnal Inovasi Pendidikan Sains, 9(1), 23-30. DOI:10.20527/quantum.vgi1.4857

Saputra, M. R. B., \& Supriyo, E. (2020). Pembuatan plastik biodegradable menggunakan pati dengan penambahan katalis zno dan stabilizer gliserol. Pentana: Jurnal Penelitian Terapan Kimia, 1(1), 41-51.

Saputro, ANC, and Ovita, AL (2017). Synthesis and characterization of bioplastic from chitosan-ganyong starch (Canna edulis). JKPK (Jurnal Kimia dan Pendidikan Kimia, 2(1), 1321. DOI:10.20961/jkpk.v2i1.8526

Siregar, R. (2016). Pengaruh plastisiser gliserol dan poligliserol asetat (PGA) terhadap biodegradasi plastik polipropilen/kitosan dengan bakteri effective microorganism 4 (Em4).Thesis. Program Studi Magister Ilmu Kimia, Universitas Sumatera Utara. Medan.

Wardana, D., Ramadhan, A., Amne, D. P. F., \& Eddiyanto, E. (2019). Utilization of glycerol from used oil as an ester glycerol surfactant. Indonesian Journal of Chemical Science and Technology (IJCST), 2(2), 111-120. DOI:10.24114/ijcst.v2i2.13999

Warzukni, I. A. (2020). Pembuatan dan karakterisasi plastik biodegradable pati porang dan kitosan dengan plasticizer gliserol. Thesis. Program Studi Fisika, Universitas Sumatera Utara. Medan. 